\title{
WOMEN AND THE HUMAN RIGHTS ACT*
}

\section{Aileen McColgan, Reader in Law, King's College London}

On 2 October 2000 the Human Rights Act (HRA), which incorporates elements of the European Convention on Human Rights into UK law, became fully implemented throughout the UK. The Act's explicit aim is to 'bring home' to UK subjects the rights guaranteed by the Convention by permitting their enforcement at the national, as well as the international, level. This, in turn, entails a transfer of some power from the legislature to the judiciary. British judges will be empowered to interpret existing legislation in accordance with the incorporated rights, to strike down secondary legislation inconsistent with those rights and to issue 'declarations of incompatibility' in respect of primary legislation. The legislature will not be obliged to remedy primary legislation in the face of a declaration of incompatibility, but it has accepted by all concerned that failure to take remedial action is likely to be very rare. ${ }^{1}$

There is a general presumption on the part of those of a liberal bent that 'rights' are, in general, a 'good thing'. The aim of this article is to challenge that presumption by examining the impact of entrenched rights (as distinct from 'normal' statutory rights such as those to be found in the Sex Discrimination (Northern Ireland) Order 1976) upon women. Given space constraints, no detailed analysis of the provisions of the HRA or of the European Convention on Human Rights will be attempted.

'Entrenched' or 'constitutional' rights are generally characterised by a level of abstraction not common to statutory rights. This abstraction, which renders them of general application, also means that this application turns upon their interpretation by the judiciary. It will be argued that judges have not, by and large, served women's interests. This has, in part, resulted from sexist assumptions embedded within the common law and translated therefrom into judicial notions of fairness and reasonableness. But other dangers inherent in entrenched rights are not unique to women, being connected with factors such as their relative disadvantage and vulnerability in the 'private' sphere.

Entrenched rights have the potential to curb the excesses of government. But they may also serve to combat progressive forces. In 1997, Ireland's Supreme Court struck down legislation which required employers to make reasonable accommodation for disabled workers on the grounds that it violated employers' constitutionally protected property rights. And the

As will be evident from the references throughout, this paper draws heavily on my recently published Women Under the Law: the False Promise of Human Rights (Addison, Wesley, Longman, 2000).

1 See Rights Brought Home: the Human Rights Bill (1997, CM 3782) (available on the world wide web at -

http://www.official-documents.co.uk/document/hoffice/rights/rights.htm), para 2.10, statements by the Home Secretary Jack Straw 16 Feb 1998 (HC Debs, col. 772) and 21 October 1998 (col. 1301), and by Lord Borrie, HL Debs 3

November 1997, col.1275. 
history of the US Supreme Court in thwarting remedial social legislation is well known. ${ }^{2}$ The power given to the judiciary by the HRA does not, in theory, permit that body to override the Parliamentary will. But the interpretative obligations placed upon judges by the Act, together with the likely political impact of any declarations of incompatibility, serve radically to increase in practical terms the power of the judiciary vis-à-vis that of Parliament.

In order to consider some of the possible implications for women of the HRA, it is useful to consider the experience of entrenched rights in other jurisdictions as well as some of the jurisprudence relating to the ECnHR (which jurisprudence must - section 2 - be taken into account in the application of the HRA). The experience in Canada and the US is particularly instructive, not least because of the broadly liberal nature of the rights there entrenched (South Africa's post-Apartheid Constitution, by contrast, also embraces social and economic rights), but also because they stand at opposite ends of the spectrum in terms of date of entrenchment ${ }^{3}$ and, accordingly, in their approaches to issues of discrimination and equality.

No attempt will be made, within the constraints of this article, to survey the impact of entrenched rights across the whole spectrum of women's lives in order to determine whether, on balance, entrenchment is beneficial or otherwise to them. No survey could capture the variety of possible approaches to entrenchment, of specific rights entrenched and qualifications thereto, much less the wealth of differences between women and the diverse aspects of their lives on which entrenched rights may impact. Whether, for example, the operation of Canada's Charter is, taken in the round, beneficial or detrimental to a particular woman will turn on her marital and parental status; sexual orientation; participation or otherwise in paid work and, in the case of participation, position within the public or private sector and within a female or male-dominated or gender-balanced occupational or industrial sector. It will also turn on her membership or non-membership of a trade union; her experience or otherwise of domestic violence, sexual assault or other criminal behaviour; her participation or non-participation in criminal activity and her financial position. ${ }^{4}$ The aim of this paper is, rather, to suggest that entrenchment may not be as unmixed a blessing as those on the left tend to believe, and to point to some issues which may prove particularly problematic from a feminist perspective. In order to make this point, the impact of entrenched rights upon women as reproducers, as producers and as victims of violence will be considered.

\section{Constitutional rights and reproductive freedom}

It is clear from the experience elsewhere that women have gained some benefits from entrenched rights. A frequently cited (though not universally accepted) example is the decision in Roe $\mathrm{v}$ Wade $(1973)^{5}$, in which the US Supreme Court ruled that women's access to abortion was protected by the

2 See further A.McColgan, Women Under the Law, Chapter 2.

3 In the US, broadly the late 18th century, with those provisions of most concern to us having been embraced largely in the late 19th Century: in Canada, 1982.

4 See McColgan, note 2 above, Chapters 4-9.

5410 US 113. 
constitution. Similarly, in Morgentaler $(1988)^{6}$, Canada's Supreme Court ruled that the Charter of Rights was breached by legislation which severely restricted access to abortion. But Germany's Bundesverfassungsgericht (Supreme Constitutional Court) has twice struck down restrictive abortion legislation on the grounds that, by failing to criminalise the procedure, it provided inadequate protection to the foetus which was required by the constitutionally protected right to life. And in Ireland the High Court's reading of the constitution resulted, in 1992, in an order requiring the return of a 14 year old girl from England and prohibiting further travel by her for the duration of her pregnancy. Sexually assaulted over a period of years by an adult man, she had travelled to England with her parents in order to have an abortion. Despite the Constitution's recognition of the 'equal right to life of the mother' and medical evidence of a risk of suicide and the probability of devastating injury to the girl's mental health if she were forced to carry the pregnancy to term, it was not until the matter reached the Supreme Court that the order was lifted and the girl permitted to travel abroad in order to secure an abortion a month later than would otherwise have been the case. ${ }^{7}$

The decision of Canada's Supreme Court in Morgentaler resulted in the repeal of the offending legislation which has not, to date, been replaced. This repeal was greeted by one commentator at the time as "perhaps the only unqualified good result to come from the Supreme Court of Canada yet". ${ }^{8}$ But the impact in the US of Roe $\mathrm{v}$ Wade is more difficult to assess. In 1985 the New Republic suggested that the decision was the "worst thing that ever happened to American liberalism. Almost overnight it politicized millions of people and helped create a mass movement of social conservatives that has grown into one of the most potent forces in our democracy". 9 One amicus curiae in the Roe $\mathrm{v}$ Wade proceedings warned that "one of the most dangerous things that could happen now is that women could sit back and think that they had won". But the anti-abortion industry which developed in the US after 1973 was not matched by the activities of pro-choicers. And, while the decision struck down all state abortion legislation then in force, it was followed (and continues to be followed) by a tidal wave of restrictive statutes only some of which have been successfully challenged on constitutional grounds ${ }^{10}$.

The political power of the anti-abortion lobby in the US is such that legislative assaults on access to abortion are easy vote winners. Although a majority of Americans still support abortion, politicians can point-score by supporting very restrictive legislation in the knowledge that it will be struck

6 [1988] 1 SCR 30.

7 Attorney General v $X$ and others [1992] IRLM 401, [1992] 1 IR 1. The Irish and German examples are, with those of the US and Canada, further discussed in McColgan, note 2 above, Chapter 4.

8 M. Mandel, The Charter of Rights and the Legalization of Politics in Canada (Toronto: Wall \& Thompson Inc, 1989) p 287.

925 February 1985, cited by L. Epstein and J. Kobylka, The Supreme Court and Legal Change: Abortion and the Death Penalty (1992: University of North Carolina Press, Chapel Hill), p 207.

10 See McColgan, note 7 above. 
down on constitutional grounds. ${ }^{11}$ At the same time the Supreme Court, stacked under Presidents Reagan and Bush with political conservatives, has continued to dilute the constitutional protection afforded by Roe $\mathrm{v}$ Wade. ${ }^{12}$ This unholy alliance was remarked upon by Justice Blackmun, who wrote the majority decision in that case but, by the 1980s, had found himself in a minority. In Webster v Reproductive Health Services (1989), in which the Supreme Court upheld legislation which prohibited any but life-saving abortions being carried out in "any physical asset owned, leased, or controlled by [the] state or any agency or political subdivisions thereof", Blackmun protested that the majority "implicitly invites every state legislature to enact more and more restrictive abortion regulations in order to provoke more and more test cases, in the hope that sometime down the line the Court will return the law of procreative freedom to the severe limitations that generally prevailed in this country before January 22, 1973 [the date of the decision in Roe v Wade]". ${ }^{13}$

Abortion continues to be a extraordinarily significant election issue in the US $^{14}$ and has, at times, played a major role in judicial appointments. ${ }^{15}$ This was most evident in the Senate Hearings concerning Clarence Thomas prior to his Supreme Court appointment. But President Bush, who was determined to have Roe $\mathrm{v}$ Wade overturned, did his utmost to appoint only those opposed to abortion at all levels of the judiciary. Such appointees being perhaps more inclined than others towards social conservatism, the repercussions of Bush's anti-abortion policy have been felt across the spectrum of judicial decisionmaking. ${ }^{16}$

The final point which arises in connection with abortion is one of more general application. The US Supreme Court has consistently refused to rule that the right of access to abortion (even in its 1970s heyday) is more than a negative freedom. Abortions are available under Medicaid (which provides 'medically necessary' health care for the lowest-income Americans) only where the woman's life (or, according to the political composition of the government, her health) is at stake. ${ }^{17}$ Justice Brennan protested in his dissent in Maher v Roe, in which a majority of the Supreme Court upheld the exclusion of abortions from Medicaid, that funding childbirth, while refusing to fund abortions, "clearly operates so as to coerce indigent pregnant women

11 Chicago Tribune 2 February 1995 "support for a bill that restricts abortion will protect [politicians] from likely attacks from abortion opponents in upcoming elections". Even liberal politicians could, according to the Tribune, use their support for a restrictive law "to defend themselves against opposition from the Right". See also Epstein and Kobylka, note 9 above, pp 219-20, citing E. Rubin, Abortion, Politics and the Courts: Roe v Wade and its Aftermath (New York: Greenwood Press, 1987) p 131.

12 McColgan, note 7 above.

13492 US 490.

14 McColgan, note 7 above.

15 See R. Dworkin, Freedom's Law, (Cambridge, Mass: Harvard University Press, 1996), p 147.

16 See, for example, the discussion of affirmative action below and in McColgan, note 2 above, Chapter 7.

17 The 'Hyde amendment' to the Public Health Service Act, upheld by the Supreme Court in Maher v Roe 432 US 464 (1977) and in Harris v McRae, 448 US 297 (1980), and varying in its severity from time to time. 
to bear children they would not otherwise choose to have, and just as clearly, this coercion can only operate on the poor, who are uniquely the victims of this form of financial pressure." 18 But despite continuing dissent, the Supreme Court has continued to uphold the 'right to choose' as a purely negative freedom ${ }^{19}$ which does not entitle women to abortions carried out in publicly-funded facilities or by publicly-funded personnel, or to information about, or referrals for, abortion through family planning programmes funded by the state. ${ }^{20}$

The issue of funded abortions illustrates a more general point about entrenched rights. Generally enforceable only against the state, such rights are intended "to restrain government, to protect the negative freedoms of citizens - freedom from the long arm of the state" 21 . This point will be pursued further below.

\section{Constitutional rights and workplace equality}

Abortion is generally regarded as an area in which entrenched rights have operated to the benefit of women. We have seen, above, that this is not wholly accurate. The likely impact of the Human Rights Act in this context is considered below. But another area in which women would perhaps generally be regarded as likely to benefit from entrenched rights concerns workplace discrimination. There is abundant evidence (but insufficient space here to discuss it) that women suffer from discrimination in the workplace. The latest Cabinet Office sponsored research suggests an earning gap of between $£ 143,000$ and $£ 241,000$ between similarly skilled childless women and men over a lifetime ${ }^{22}$, childbearing costing women up to an additional $£ 285000$ in earnings where they comply with the normal patterns of return for low-skilled women $(£ 285,000)$, mid-skilled women $(£ 140,000)$ or highly skilled women $(£ 19,000)$. As the research notes, highly skilled women who retain their position in the workforce do so at very significant expense in terms of childcare costs.

The impact on workplace equality of entrenched rights has differed significantly between the US and Canada. A fundamental preliminary point concerns the application of entrenched rights generally. Whereas much of the threat to women's reproductive autonomy emanates from the state itself, with the effect that it may be constrained by vertically effective entrenched rights, most of the threat to women's workplace equality issues from the market. To the extent that women are legally prohibited from entering certain occupations, and so forth, entrenched rights can provide a basis for challenge. ${ }^{23}$ But their role in actions against private sector employers is less

18 Griffin v Illinois 351 US 12, 23 (1956).

19 Harris, Webster and Rust v Sullivan 500 US 173 (1991).

20 Ibid.

21 P. Russell, "The political purposes of the Charter: have they been fulfilled? An agnostic's report"; in P. Bryden et al (eds), Protecting Rights and Freedoms: Essays on the Charter's Place in Canada's Political, Legal and Intellectual Life (Toronto: University of Toronto Press, 1994), p 40.

22 The size of the gap depends on whether the woman and her comparator are lowskilled ( $£ 197,000$ or $37 \%$ of lifetime earnings), high-skilled ( $£ 143000$ or $12 \%$ ) or mid-skilled ( $£ 241,000$ or $37 \%)$.

23 As in the US, see McColgan, note 2 above, Chapter 6. 
certain. Canada's Supreme Court has adopted a very narrow approach, applying the Charter only to the activities of 'government' narrowly defined ${ }^{24}$ and to other bodies only in relation to 'inherently governmental actions' delegated to them. It has also, and to roars of condemnation, refused to apply the Charter to the common law. ${ }^{25}$ Thus, in RWDSU v Dolphin Delivery Ltd, that Court held that an injunction against secondary action, which was issued at common law, was not vulnerable to Charter review. The approach taken by the US courts has been more generous, constitutional protections generally being regarded as applicable to actions 'under color of law' (actions permitted, whether or not required, by $l \mathrm{aw}^{26}$ ) and to the common law. ${ }^{27}$

Canada's Charter has been applied to declare unlawful a provision restricting the size of pay increases to be awarded under legislation designed to tackle the gender-wage gap. ${ }^{28}$ It has also been applied to prevent the repeal of a legislative provision designed to enable otherwise excluded women to benefit from such legislation. ${ }^{29}$ These decisions are consistent with that of the Supreme Court in Eldridge v British Columbia ${ }^{30}$ to the effect that: "once the state does provide a benefit, it [must] do so in a non-discriminatory manner". ${ }^{31}$ But, although a number of Supreme Court justices have suggested that "a government could properly be subjected to a challenge under section $15 \ldots$. . for failing to act at all" 32 , such hints have yet to be followed in practice.

In Eldridge La Forest J, for the Court, left open the possibility that section 15 of the Charter might "oblige the state to take positive actions to ameliorate the symptoms of systemic or general inequality". ${ }^{33}$ But in Ferrel v Ontario (1997), in which Ontario's Divisional Court rejected a Charter challenge to the repeal of proactive anti-discrimination legislation, Dilks $J$ took the view

24 See McKinney v University of Guelph [1990] 3 SCR 229; Stoffman v Vancouver General Hospital [1990] 3 SCR 483.

25 RWDSU v Dolphin Delivery Ltd [1986] 2 SCR 573, [1986] 2 SCR 573

26 American Federation of Labor v Swing (1941) 312 US 321 (1941); Shelley v Kraemer 334 US 1 (1947); Lugar v Edmondson Oil Co 457 US 922; Jackson v Metropolitan Edison Co 419 US 345 (1974); Lebron v National Railroad Passenger Corporation (Case no. 93-1525, 1995).

27 Swing, ibid.

28 Manitoba Council of Health Care Unions v Bethesda Hospital (1992) 88 DLR (4th) 60.

29 Re Service Employees International Union, Local 204 et al. and Attorney General of Ontario, SEIU, Local 204 v Ontario (Attorney General), 151 DLR 4th 273, Ontario Court (General Division). The government subsequently announced its decision not to appeal - Toronto Sun 8 October 1997.

30 [1997] 3 SCR 624.

31 Eldridge, ibid, para 73, per La Forest J citing Tétreault-Gadoury v Canada [1991] 2 SCR 22; Haig v Canada [1993] 2 SCR 995; Native Women's Assn. of Canada v Canada [1994] 3 SCR 627 and Miron v Trudel [1995] 2 SCR 418.

32 Lamer CJ for the majority in Vriend [1998] 1 SCR 493 noted that this possibility had been left open by Heureux-Dubé $\mathrm{J}$ for the majority in Haig; by Dickson CJ in Reference re PSERA (Alberta) [1987] 1 SCR 995 and by La Forest J for the Court in Eldridge.

33 Morden ACJO in Ferrel v Ontario (Attorney General) 1998 CRDJ 79; 1998 CRDJ LEXIS 141 (Ont CA) for the Court. 
that: "The application of the Charter must be confined to government action as opposed to inaction ... The overwhelming weight of authority negates the existence of any duty under the Charter to legislate". ${ }^{34}$

Ontario's Court of Appeal rejected the subsequent appeal, Morden ACJO for the Court citing, inter alia, Dickson J (later Chief Justice) in Hunter v Southam Inc: "[the Charter] is intended to constrain governmental action inconsistent with those rights and freedoms; it is not in itself an authorization for governmental action" 35 and La Forest J (now Chief Justice), in McKinney v University of Guelph: "This Court has repeatedly drawn attention to the fact that the Charter is essentially an instrument for checking the powers of government over the individual" 36 . Morden ACJO also pointed out that "[h]istorically, Bills of Rights . . . have been directed at government. . . While subjecting private activities directly to review under the Charter is not the same thing as interpreting section 15(1) as imposing a duty on legislatures to enact legislation to govern private activities [similar considerations apply]. . . Legislatures have flexibility and a wide range of choices. Courts, acting under the Charter, have no guidance in making their determinations of what the Charter requires of legislatures".

The limitations on the application of the Charter otherwise than to "government" very narrowly defined have served to neuter the potentially radical impact of the Supreme Court's approach to 'discrimination' under that Charter. Whereas, as we shall see further below, the US Supreme Court have adopted a very formal, conservative approach to the equality provisions (such as they are) of the US Constitution, Canada's Supreme Court embraced a substantive model of equality from the start. In Law Society of British Columbia v Andrews ${ }^{37}$, discrimination was defined to include its indirect as well as its direct form $^{38}$ and the Court ruled that "every difference in treatment between individuals under the law will not necessarily result in inequality and .... identical treatment may frequently produce serious inequality". In this and in subsequent cases that Court ruled that a demonstration of discrimination under section 15 requires an examination of "the larger context [in order] that a court can determine whether differential treatment results in inequality or whether, contrariwise, it would be identical treatment which would in the particular context result in inequality or foster disadvantage. A finding that there is discrimination will, in most but in perhaps not all cases, necessarily entail a search for disadvantage that exists

34 Ont Gen Div 9 July 1997, citing Iacobucci J in Symes v Canada [1993] 4 SCR 695 and Board of Education of Kiryas Joel Village School v Grunet (1994) 124 US 2481. See also the unanimous decision in $R$ v $S(S)$ [1992] 2 SCR 254, in which the Court ruled that the non-exercise of discretion by the Attorney-General (there to establish alternative programmes for young offenders) could not be reviewed under s. 15 of the Charter.

35 [1984] 2 SCR 145, p 156.

36 Note 24 above, pp 261-263.

37 [1989] 1 SCR 143.

38 Justice Wilson going so far as to state that: "s 15 is designed to protect those groups who suffer social, political and legal disadvantage in our society". See also Eaton v Brant County Board [1997] 1 SCR 241 and Eldridge, note 30 above. 
apart from and independent of the particular legal classification being challenged". 39

The approach taken by Canada's Supreme Court has permitted it to find that unequal restrictions on the employment of male and female prison officers in, respectively, female and male prisons, did not amount to discrimination under section 15. In Conway v Canada (Attorney General) ${ }^{40}$, male prisoners challenged their subjection to surveillance and 'frisk' searches by women guards on the grounds that male guards were not permitted to perform these functions in relation to women prisoners. La Forest $\mathbf{J}$ declared, for the unanimous Court, that "the historical trend of violence perpetrated by men against women is not matched by a comparable trend pursuant to which men are the victims and women the aggressors. . . the effect of cross-gender searching is different and more threatening for women than for men. The different treatment to which the appellant objects thus may not be discrimination at all". In the US, by contrast, the non-discrimination guarantee is regarded as requiring that male prison guards perform the full range of duties in female prisons with the effect that male-on-female sexual violence is commonplace throughout the prison system. ${ }^{41}$

The US Constitutional jurisprudence relating to discrimination has been very different. Part of this difference results from the distinct Constitutional provisions. Section 15 of Canada's Charter provides that: "Every individual is equal before and under the law and has the right to the equal protection and equal benefit of the law without discrimination and, in particular, without discrimination based on race, national or ethnic origin, colour, religion, sex, age or mental or physical disability". By contrast, discrimination is regulated by the Equal Protection Clause of the $14^{\text {th }}$ Amendment to the US Constitution which provides that "nor shall any State . . . deny to any person within its jurisdiction the equal protection of the laws". ${ }^{42}$ This provision was not applied to sex discrimination until the midtwentieth century. When it was, the Supreme Court ruled that such discrimination could be justified if it was reasonably necessary in pursuit of a permissible and important aim. ${ }^{43}$ This is the 'intermediate standard' of scrutiny, race discrimination being subject to 'strict scrutiny' (it will be unconstitutional unless 'necessary' or 'narrowly tailored' to promote a 'compelling interest' of government) and other forms of discrimination to the 'relaxed' standard of review (most classifications are acceptable if they are not totally irrational or utterly arbitrary).

The US Supreme Court has refused to categorise pregnancy-related discrimination as sex discrimination. But perhaps the most significant

39 Turpin [1989] 1 SCR 1296. Cf Thibaudeau v Canada [1995] 2 SCR 627; Miron, note 31 above and Egan v Canada [1995] 2 SCR 513. Most recently see Law v Canada [1999] 1 SCR 497 and Lovelace v Ontario 20 July 2000, available at http://www.lexum.umontreal.ca/csc-scc/en/rec/html/lovelace.en.html.

40 [1993] 2 SCR 872.

41 The Human Rights Watch Global Report on Women's Human Rights (New York: Human Rights Watch, 1995), Chapter 3.

42 Applied by analogy to federal action through the due process clause of the $5^{\text {th }}$ Amendment.

$43 \mathrm{~S} 15$ is subject to s1's provision permitting such "reasonable limits prescribed by law as can be demonstrably justified in a free and democratic society". 
limitation on the Equal Protection Clause lies in its non-application, as interpreted, to unintentional indirect discrimination. ${ }^{44}$ An intention to discriminate requires, not merely that the body imposing the rule knew of its disparate impact, but also that the decision maker "selected or reaffirmed a particular course of conduct at least in part "because of", not merely "in spite of", its adverse effects upon an identifiable group." 45 Even if an intention to discriminate was one of the reasons behind the imposition of a disparatelyimpacting practice, the $14^{\text {th }}$ Amendment will be violated only if the rule would not have been imposed even in the absence of this motive. ${ }^{46}$ Finally a number of Supreme Court decisions require that, when evaluating the evidence to ascertain whether discriminatory intent has been established, each be considered separately and discriminatory intent be found only if this can be done on the basis of one or more factors viewed in isolation. ${ }^{47}$ The application of the Equal Protection Clause to direct discrimination alone "means if men don't need it, women don't get it". ${ }^{48}$

The equality provisions of the US Constitution fall well short, in their application, from those of Canada's Charter of Rights. This is evident above but even more so in the context of 'affirmative action'. The relationship recognised by Canada's Supreme Court between 'discrimination' and 'disadvantage' has been mentioned above. Further, section 15(2) of the Charter provides that section 15(1) does not apply to "any law, program or activity that has as its object the amelioration of conditions of disadvantaged individuals or groups including those that are disadvantaged because of . . . sex".

Section 15(2) has not been applied by the Supreme Court. But in 1987, prior to its implementation, the Supreme Court gave its stamp of approval to affirmative action in Action Travail des Femmes v CNR (1987), in which it upheld an order of Canada's Human Rights Commission that at least 25 per cent of appointees to traditionally male, blue-collar jobs be women until the proportion of women in that sector of the workforce reached a minimum of 13 per cent (this being the average level of participation of women in such jobs nationwide). ${ }^{49}$ The Supreme Court accepted that 'systematic discrimination' (defined as "discrimination that results from the simple operation of established procedures of recruitment, hiring and promotion, none of which is necessarily designed to promote discrimination") had occurred and that the programme ordered was "essential to combat [its] effects". According to that Court, the Commission had to be given generous scope to remedy such systemic discrimination: "to render future discrimination pointless, to destroy discriminatory stereotyping and to create the required 'critical mass' of target group participation in the workforce, it

44 Washington v Davies, 426 US 229 (1976).

45 Massachussetts Personel Administrator v Feeney 442 US 256 (1979).

46 Village of Arlington Heights v Metropolitan Housing Development Corp 429 US 252 (1977).

47 City of Mobile v Bolden 446 US 55 (1980). Cf. Rogers v Lodge 458 US 613 (1982).

48 Catherine MacKinnon, cited in K. Mahoney, Charter Equality: The First Twelve Years, paper presented to the Warwick Legal Research Institute Rights and Democracy in Canada and the UK Conference, 17 May 1997, p 13.

49 [1987] 1 SCR 1114. 
is essential to combat the effects of past systemic discrimination. . . specific hiring goals. . . are a rational attempt to impose a systemic remedy on a systemic problem". ${ }^{50}$

More recently, in Lovelace $\mathrm{v}$ Ontario, the Supreme Court ruled (per Iacobucci J) that section 15(2) could best be understood as "confirming the substantive equality approach of s 15(1)", although he did not "foreclose possibility that s 15(2) may be independently applicable to a case in the future ... claimants arguing equality claims in the future should first be directed to $s$ 15(1) since that subsection can embrace ameliorative programs of the kind that are contemplated by s 15(2)."

The approach taken by the US Supreme Court to affirmative action has been significantly different and the Equal Protection Clause, having failed significantly to reduce the disadvantage suffered by women and ethnic minorites in the workplace, threatens to undo legislative attempts to combat systemic discrimination by positive means. In Regents of the University of California v Bakke (1978) $)^{51}$, the Supreme Court struck down a quota-based admissions programme operated by the university's medical faculty in an attempt to ensure the admission of ethnic minority candidates into medical training (as Justice Brennan pointed out in his dissent, minority applicants were disadvantaged by segregated schooling). ${ }^{52}$ The minority judges took the view that strict scrutiny of race discrimination was inappropriate when applied to remedial action. The majority disagreed.

Bakke left open some forms of affirmative action. Justice Powell, who joined the bare majority, accepted that remedial action could pass muster under the strict scrutiny test (this being a race case) where it was directed at past discrimination by the particular body, and that universities could have a compelling interest in taking steps to secure a diverse student group, although he demanded 'narrow tailoring' of means to this end and drew the line at rigid quotas to achieve this purpose. The approach of the Supreme Court to affirmative action has wavered over time but what can be said with certainty is that the US Constitution has stood as an impediment to attempts radically to tackle systemic disadvantage. In recent years the approach of that Court appears to have hardened, Adarand Constructors v Pena (1995) being regarded by many as having delivered a mortal wound to the future of affirmative action programmes..$^{53}$

\section{Violence and Entrenched rights}

One of the most problematic aspects of entrenched rights, from a feminist perspective, concerns their application in the criminal context. Women are, although perhaps less likely to be victim to violent crime than men, disproportionately likely to be the victim rather than the perpetrator of such crime. Constitutional safeguards of the rights of suspects and defendants

50 Ibid, p 1145 per Dickson LCJ.

51438 US 265 (1978).

52 Prohibited by the Supreme Court in Brown v Board of Education 347 US 483 (1954).

53 Case no. 93-1841, 1995. For discussion of the repercussions of this decision and of the general trend of Supreme Court decisions on the affirmative action issue see McColgan, note 2 above, Chapter 7. 
therefore have particular implications for women who are more likely to suffer their constraints then to benefit from them. This is not to argue that such safeguards should not be applauded, rather simply to point out a gender issue related to them. Where this gender issue becomes particularly significant is where those safeguards are applied in a manner which is intrinsically hostile to the interests of women, that is, in the area of sexual offences.

Sexual and other violence against women, generally carried out by men known to them, is endemic. In 1998 the British Medical Association estimated that one in four women in the UK has been the victim of domestic violence. ${ }^{54}$ In London in 1982, Women Against Rape found that one woman in every six had been raped, and that a further one in five had suffered an attempt. ${ }^{55}$ One in seven married women had been raped by their husbands. The number of reported rapes has been increasing $(8,500$ in 1999 by comparison with 1,850 in 1985). ${ }^{56}$ The Observer reported on 30 July 2000 that the conviction rate had "fallen to a record low", citing Home Office statistics to the effect that only 634 (7.5 per cent) of the rapes reported to the police in 1999 resulted in convictions. This is not to say that 7.5 per cent of women raped see their attackers convicted. Of the 50000 women who report rapes to the Rape Crisis Federation each year, only 7 per cent contact the police.

The attrition rate for rape, both at the trial stage and before, is very high. In particular, women find it next to impossible to have their intimates convicted and women whose lifestyles and sexual behaviour do not fit the stereotype of chaste Victorian wife or virgin are especially disadvantaged. The courtroom significance of factors personal to the rape complainant feed back into the pre-court proceedings and, no doubt, explain in part the high 'no-criming' and other non-prosecution decisions in rape complaints where the alleged offender is identified (around 70 per cent in 1999). ${ }^{57}$

Recognition of the impact on the conviction rate of evidence about women's sexual behaviour has resulted in legislative attempts to curtail the introduction of such evidence in many jurisdictions. In both Canada and the US, the constitutionally entrenched rights of defendants have resulted in the striking down of some such provisions. In Seaboyer ${ }^{58}$, for example, Canada's Supreme Court ruled that the 'rape shield' provisions of the Criminal Code breached the accused's right to a fair trial. In doing so, and despite her repeated assertions that the sexual conduct of complainants was relevant neither to their credibility nor, in general terms, to the likelihood of their consent, a number of the situations in which Madam Justice McLachlin, for the majority, regarded sexual history evidence as potentially relevant

54 Guardian, 7 July 1998.

55 R. Hall, Ask Any Woman: London Inquiry into Rape and Sexual Assault (Bristol, Falling Down Press, 1985).

56 Observer 30 July 2000

57 Ibid.

58 [1991] 2 SCR 577. 
relied in part upon these very "outmoded and illegitimate notions" concerning credibility and consent. ${ }^{59}$

Canada's Charter was put to further use by the defendant in Osolin in which the Supreme Court ruled that the defendant's right to a fair trial required that he be permitted to cross-examine the complainant on mental health records which had previously been admitted into evidence on the issue of her competence to testify. ${ }^{60}$ In $O^{\prime}$ Connor, the same Court ruled that the complainant had no privacy interest in counselling and medical records already disclosed to the prosecution and that relevance to the defence "must be presumed where the records are in the Crown's possession." 61 Subsequently in Carosella (1996) the Court stayed proceedings against a man charged with sexual assault. ${ }^{62}$

Notes taken of an interview between the complainant and a counsellor at a sexual assault clinic had been destroyed in line with the policy of the clinic. The stay was granted on the basis that the destruction of the notes "had seriously prejudiced the accused by depriving him of the opportunity to cross-examine the complainant as to her previous statements relating to the allegations she made" and that, accordingly, his "Charter right to make full answer and defence had been breached". The sexual assault centre was not an agency bound by the Charter and it was under no obligation to make, much less to retain, records of its interviews with sexual assault complainants. Further, as was pointed out at the time of the original stay of prosecution, the effect of the order was to "requir[e] those counselling the victims of sexual abuse to become evidence gatherers - investigators - for the defence. . . Services and relationships that were established to. . . assist survivors of sexual abuse in healing, are being subverted as they are drawn increasingly into the litigation process". ${ }^{63}$ The logic of Carosella applies in equal measure to a diary allegedly kept but subsequently destroyed or mislaid by the complainant. Canada's defence lawyers are now subpoenaing journals, as well as "counseling notes, employment and academic records, medical files and more". ${ }^{64}$

Seventeen months after the decision in O'Connor, Canada's Parliament established a statutory procedure for disclosure of personal records, whether those records are in the hands of the prosecution or not. ${ }^{65}$ In Mills (1997), Alberta's Court of Queen's Bench struck down the legislative restrictions on disclosure on the grounds that they were inconsistent with the Supreme Court's decision in O'Connor. ${ }^{66}$ The Supreme Court ultimately overruled

59 For further discussion of this see McColgan, note 2 above, Chapter 9 and "The relevance of sexual history evidence" (1996) 16 Oxford Journal of Legal Studies 275.

60 [1993] 4 SCR 595.

61 [1995] 4 SCR 411.

62 [1997] 1 SCR 80.

63 J. Gilmour, "Counselling records: disclosure in sexual assault cases", in J. Cameron (ed), The Charter's Impact on the Criminal Justice System (Scarborough, Ontario: Carswell, 1996), 239, pp 256-7.

64 Chatelaine, October 1997.

65 Unless the complainant has expressly waived privacy in records in prosecution hands.

66 (1997) CRR Lexis 97, Alberta QB. See also Lee, (1997) CRR Lexis 100, Ontario. 
that decision and confirmed the constitutionality of the legislative restrictions. ${ }^{67}$ Nevertheless, the overall effect of Charter jurisprudence in this area has been to the significant detriment of those who suffer sexual assault.

It is not here suggested that the right to a fair trial can justifiably be infringed. But the question which arises concerns the courts' conception of what a 'fair trial' demands. In Mills, McLachlin and Iacobucci JJ, for the majority, evinced an understanding of the section 7 right to a fair trial which took into account the complainant's interests in privacy and (given the relationship between privacy of therapeutic records and the complainant's 'mental integrity', her) security of the person:

"under section 7 rights must be defined so that they do not conflict with each other. The rights of full answer and defence, and privacy, must be defined in light of each other, and both must be defined in light of the equality provisions of section 15 ... the first question to ask is how to define full answer and defence, privacy, and equality in this context, and not how they may be justifiably limited."

The Court went on to decide that the legislative provisions adequately safeguarded the accused's section 7 rights by permitting disclosure of information which directly bore on the right to make full answer and defence. But in Seaboyer and in O'Connor, this approach had been taken only by the minority. The decisions in these cases and in Carosella cast doubts on the ability of the courts to revisit common law notions of fairness taking into account the constitutionally protected rights of the complainant. When it comes to the 'balance' between the 'right to a fair trial' and the complainant's interests in privacy, security of the person or the equal protection of the law, the accused's 'right to a fair trial', understood decontextualised from the rights of the complainant, can operate to trump any other considerations. Thus, only evidential or procedural restrictions which do not infringe upon the defendant's fair trial rights as those rights are understood under the common law are upheld. ${ }^{68}$

67 [1999] 3 SCR 668.

$68 R$ v L (DO) [1993] 4 SCR 419; Levogiannis [1993] 4 SCR 475. See also Canadian Broadcasting Company v Attorney General for New Brunswick [1996] 3 SCR 480. $C f$, on similar facts, the US decisions in Coy v Iowa (1988) 487 US 1012. See also (on sexual history evidence), Shaw v United States 892 F Supp. 1265, Hoke v Thompson 589 F Supp. 206, US v Fuller 589 F. Supp. 206, United States v Kasto, 584 F.2d 271, Doe v United States, 666 F 2d 48, Darrow v Alabama 451 So 2d 394 (1984), People v Khan 80 Mich. App. 605; 264 NW 2d 360; Massachussets v Elder 389 Mass 743 (1983), Hubbard v State 271 Ark 937 (1973); Commonwealth v Black 337 Pa Sup Cut 548 (1985), Louisiana v Small CA $2^{\text {nd }}$ Cir, Lou 693 So 2d 180 (1997) and Giles v Maryland (1967) 386 US 66 (1967). No Supreme Court decision has yet been reached as to the constitutionality of absolute privilege accorded to the private records of complainants, but that Court, too, has generally assessed the constitutionality of statutory privileges by weighing the rights of the accused as perceived by the judges against the public interests served by the privilege: Pennsylvania v Ritchie, 480 US 39 (1987); United States v Nixon, 418 US 683 (1974); Davis v Alaska, 415 US 308 (1974) and Washington v Texas, 388 US 14 (1967). See further Hogan M, "The constitutionality of an absolute privilege for rape crisis counseling" (1989), 30 Boston College Law Review 411, 
The procedural aspects of sexual assault trials have been focused upon here. But the damage wrought by entrenched rights has not been confined to this area. In Hess and Nguyen ${ }^{69}$, Canada's Supreme Court ruled that statutory rape provisions which denied a defence to those who claimed mistake in relation to the age of an under-fourteen year old girl breached the Charter (Madam Justice McLachlin dissenting, in part, on the ground that: "all that a person need do to avoid the risk of [conviction] . . . is to refrain from having sex with girls of less than adult age unless he knows for certain that they are over fourteen.") And in Daviault ${ }^{70}$ the Court recognised intoxication as a defence to crimes including sexual assault. ${ }^{71}$ Alcohol plays a significant role in sexual assaults as it does more generally in crimes against women, and many men who assault women seek to explain and excuse their actions by reference to intoxication, as they also seek to excuse and explain their actions by reference to the behaviour of the women, and, indeed, of the children they attack. $^{72}$

Women as victims of violence have not generally been well served by constitutionally entrenched rights. These rights do not bind women's abusers. But they can limit the ability of the state to intervene on behalf of the victims of violence by safeguarding the interests of the accused with scant regard to those of the accuser. 'Rights' enable defendants to attack every legislative provision designed to ameliorate the position of the victims of gender-related crimes such as rape. And even where they involve challenges to apparently sex-neutral rules concerning the mental elements of crime (as, for example, in Daviault, in which the accused successfully argued that the inference of mens rea from drunken state violated his rights), they also appear peculiarly popular in cases involving male-on-female violence.

I have pointed out elsewhere, in relation to English criminal cases, that there is remarkably little to distinguish the nature of violence in cases in which men plead automatism (whether sane or insane) from those in which 'normal' sane and conscious men do violence to women (in D Nicholson and L Bibbings (eds), Feminist Perspectives on Criminal Law (forthcoming). Many of the authorities on automatism involve assaults by men on female intimates, the assaults conforming to the typical pattern of male violence against women. This being the case, the opening up of the scope for challenge to the rules applying to these and similar defences poses significant risks for women.

pp 470-74; White W, "Evidentiary privileges and the defendant's constitutional right to introduce evidence" (1989) 80 Journal of Criminal Law and Criminology 377 , at pp 423-25.

69 [1990] 2 SCR 906.

70 [1994] 3 SCR 63.

71 See also the four-strong dissent in Stone [1999] 2 SCR 290 in which the accused challenged the refusal of the trial judge to leave to the jury a plea of non-insane automatism brought on, it seems, by his wife's insulting words. He had stabbed her 47 times with a six-inch hunting knife before disposing of her body, arranging his affairs and fleeing to Mexico.

72 See D. Scully and J. Marolla, "Convicted rapists' vocabulary of motive: excuses and justifications", Social Problems (1984) vol. 31(5), p 530; D. Scully, Understanding Sexual Violence: a Study of Convicted Rapists (Boston, Unwin Hyman, 1990). 
Daviault just happened to involve a sexual assault as did C, Bjordal, and Jensen $^{73}$, in which the defendants based appeals on Daviault; and Brenton, in which the Supreme Court of the Northwest Territories ruled that federal legislation which sought to reverse the decision in that case violated the Charter. ${ }^{74}$ In Simpson, and in Thomas, men who had killed cohabitees appealed on the strength of Daviault. ${ }^{75}$ So, too, did the defendant in Tom who had raped and killed a prostitute. ${ }^{76}$ Of the 18 reported 'Daviault' cases (all of which involved male defendants), five concerned sexual assaults by men on women, three the deaths of the defendants' (female) cohabitees, one of a prostitute and one a serious assault on the defendant's mother. ${ }^{77}$ In one case the homicide victim was male as was an assault victim ${ }^{78}$, the other cases involving driving offences (three ${ }^{79}$ ), forced entry (one ${ }^{80}$ ) and two cases in which the identity of the victim was unclear from the report ${ }^{81}$. Further, in 1997 it was reported that the first post-Carosella case in which a stay was requested as a result of the unavailability of evidence involved a sexual assault. ${ }^{82}$ In the same year it was pointed out that women were continuing to plead guilty to the manslaughter of their abusive partners despite the decision of the Supreme Court in Lavallee which eased the path to acquittal in these cases, by recognising that the reasonableness of defensive force had to be assessed taking into account factors specific to battered women. ${ }^{83}$

73 Respectively, Ontario CA 40 WCB 2d 419; British Columbia CA 33 WCB 2d 182, Ontario CA 30 WCB 2d 479. See also Stanford Ontario Court (Provincial Division) 27 WCB 2d 248, in which Daviault was raised at first instance.

7444 WCB 2d 48. A similar decision was reached by Ontario's Supreme Court in Dunn 1999 CRDJ 441, which involved very severe male-on-male violence.

75 Respectively, British Columbia CA 42 WCB 2d 235, Supreme Court of Canada [1998] 3 SCR 535. See also Tipewan Saskatchewan QB 1998 Sask. D. Crim. LEXIS 284, in which the defence was put forward at trial stage.

76 British Columbia CA 39 WCB 2d 457. See also Royer [1996] 2 SCR 169 in which the defendant unsuccessfully tried to rely on Daviault on appeal from a conviction of murdering a 14 year old girl. According to the Toronto Star 13 October 1995, 'Royer ... boiled a pot of water and threw it on the [girl and her] mother. . .as they lay in bed reading. He then took a kitchen knife and stabbed them.'

77 Levy, Nova Scotia CA 29 WCB 2d 461.

78 Respectively, Misquadis Ontario Court (Provincial Division) 27 WCB 2d 4 and Frechette British Columbia CA 199941 WCB 2d 91.

79 DeVingt 43 WCB 2d 448, Morey, Ontario Court (General Division) 39 WCB 2d 225 and Byers, Saskatchewan Provincial Court 29 WCB 2d 136.

80 O'Flaherty, Ontario Court (Provincial Division) 26 WCB 2d 582.

81 McShane Ontario Court (Provincial Division) 30 WCB 2d 10 - criminal harassment and Wickstrom British Columbia CA 28 WCB 2d 384 (attempted murder).

82 The Lawyers Weekly 11 April 1997 (Canada), discussing $R$ v Mitchell. The application was rejected and the rejection upheld by British Columbia's Court of Appeal, the decision of which is available at:

http://www.courts.gov.bc.ca/CA/1998/ca-crimlaw.htm

83 The Lawyers Weekly 4 April 1997, reporting the results of a federal government review conducted by Ontario Provincial Court Judge Lynn Ratushny: "In its examination of more than 50 cases, the Self-Defence Review discovered that some women who had viable self-defence or provocation claims felt severely pressured to plead guilty to manslaughter-rather than risk a conviction of second-degree murder, with its mandatory sentence of life imprisonment without eligibility for 
Again, no suggestion is made that fair trials should be jeopardised. But 'fairness' is an issue determined by the very courts whose creature common law - ill-serves the interests of woman, particularly women as victims of sexual violence. 'Fairness', it seems, often operates as a one-way street and attempts made to place the [usually female] victims of sexual assault in a similar position to that of the victims of unisex violence are thwarted by the tendency of entrenched rights to privilege traditional judicial perceptions of relevance over those which are the result of conscious attempts to eradicate discrimination from the law.

Women in Canada have seen a succession of cases rendering the prosecution and conviction of alleged rapists ever more difficult and providing a defence of intoxication, to men accused, inter alia, of rape and domestic assault. And in the US, while constitutional guarantees have not enabled women to challenge the inadequacies of the law relating to rape (its historical nonapplication to husbands, requirements for 'utmost resistance', and so forth), they have permitted defendants to have women's sexual history evidence admitted in court in the face of legislative prohibitions on this practice, and to gain access to counselling and other records even where those records have been accorded absolute privilege by statute. One of the primary reasons for imbalance is the traditional view of the criminal defendant as a vulnerable individual pitted against the might of the state. While this view is frequently accurate, it does not capture the private violence to which women (and children) are subjected. The extent of this violence is only now being realised, and the entrenchment of rights can serve to ossify legal rules in line with perceptions of fairness embedded in the common law. ${ }^{84}$

\section{THE HUMAN RIGHTS ACT}

The above survey is intended only to raise questions about the application of entrenched rights in general, and their application to women in particular. The main points which have arisen concern the approach taken (by the entrenched provisions and the judges applying them) to 'discrimination' and/or 'equality'; the tendency of entrenched rights to apply exclusively in respect of 'government', and to 'protect the negative freedoms of citizens', rather than to "alter power relations, redistribute wealth, or promote social welfare", 85 and the relationship between constitutional judicial powers and the values and attitudes of the common law.

As far as the first is concerned, the approach to discrimination determines issues such as the constitutional approach to questions such as the legality of indirect discrimination and of affirmative action (not to mention the test for

parole for 10 years". This pressure was particularly acute for the mothers of young children

84 Lord Lester remarked in the House of Lords Committee stages of the Youth Justice and Criminal Evidence Bill, 1 February 1999, col. 1394, that "I love my colleagues from the criminal Bar, but I am bound to say that I find them somewhat conservative when it comes to doing anything to change the traditional elements of evidence and procedure in criminal trials".

85 Russell, note 21 above, pp 40-1: "The Supreme Court's interpretation of the Charter has minimized its impact on social and economic relations", (citing Dolphin Delivery Ltd, Reference re Public Service [1987] 1 SCR 313 and Irwin Toy [1989] 1 SCR 927) - see further McColgan, note 2 above, Chapter 6. 
justification of discrimination). The second point highlighted gives rise to difficulties in securing access to meaningful, usable rights as distinct from those which exist only in theory, and leads to problems in relation to attempts by the state to ameliorate the effects of private actions, such as entrenched employment-related discrimination. Even where legislatures (not being obliged to) act to improve the position of disadvantaged groups (whether by affording women pregnancy rights, embracing affirmative action or restricting the use of sexual history evidence in rape trials), entrenched rights can be relied upon to challenge those improvements.

The third issue raised is particularly problematic in the criminal law context. One US commentator, writing specifically about the implications of the Constitution for the admissibility of sexual history evidence, remarked that: "[t]he best method to determine whether admission [of any particular evidence] is required by the Constitution is to apply the jurisdiction's standard rules of evidence to the proffered ... . evidence. Because standard rules of evidence are premised on general principles developed over many years, exclusions of evidence under those rules are almost always constitutionally justified". ${ }^{86}$ But these rules may themselves be tainted by discrimination and prejudice (such as, for example, the traditional mistrust of sexual assault complainants), in which case constitutionally protected rights serve merely to perpetuate the discrimination suffered by the traditionally disadvantaged. This is considered further below, when we consider the likely implications for women of incorporation. First we address the more general points concerning the interpretation of 'discrimination' and the issues of state action/ positive obligations under the ECnHR and the HRA.

\section{Discrimination}

Turning to the Human Rights Act itself, the approach incorporated from the European Convention to 'discrimination' is less than satisfactory. It need hardly be reiterated here that the Convention contains no free-standing prohibition on discrimination, Article 14 providing only that: "[t]he enjoyment of the rights and freedoms set forth in this Convention shall be secured without discrimination on any ground such as sex, race, colour, language, religion, political or other opinion, national or social origin, association with a national minority, property, birth or other status". Article 14 does not require the violation of another right under the Convention in order to come into operation ${ }^{87}$ but "there can be no room for [the] application [of Article 14] unless the facts at issue fall within the ambit of one or more" substantive Articles. ${ }^{88}$

The next point to make about Article 14 is that its concept of discrimination is not as sophisticated as that embraced by EC law. Whereas indirect discrimination is well developed as a matter of EC law, alleged violations of

86 D. Haxton, "Rape shield statutes" (1985), Wisconsin Law Review 1219, pp 127172 , cited by L'Heureux-Dubé J in Seaboyer, note 58 above.

87 Abdulaziz, Cabales, and Balkandali A 94 (1985), p 35. This was recognised also by the Commission in $X \mathrm{v}$ Federal Republic of Germany DR 18 (1980) 216.

88 Abdulaziz, ibid; Rasmussen (1984) A 87, p 12. 
Article 14 generally involve direct and overt discrimination ${ }^{89}$. In the Belgian Linguistics case the ECtHR suggested that Article 14's prohibition extended to the 'effects' as well as the 'aims' of legislation - that is, to indirect as well as direct discrimination..$^{90}$ But Harris et al suggest that "the burden upon the applicant to establish that it exists is severe" and, as we shall see below, the justification of such discrimination is relatively easy. ${ }^{91}$

Direct, as well as indirect, discrimination can be justified under Article 14 . This is inevitable given the wide and inexhaustive grounds covered by Article 14, but it has reduced the protective potential of that provision in the context of sex discrimination. In the Belgian Linguistics Case the ECtHR ruled that Article 14 is violated by discrimination having "no objective and reasonable justification", discrimination in pursuit of a "legitimate aim" being justified unless it was "clearly established that there is no reasonable relationship of proportionality between the means employed and the aim sought to be realized". ${ }^{92}$ Under EC law, by contrast, the burden is on the alleged discriminator to justify indirect sex discrimination as "correspond[ing] to a real need, appropriate with a view to achieving the objectives pursued and necessary to that end"93. Finally, Article 14 permits the 'remedy' of discrimination by levelling-down. So, for example, when in Abdulaziz Britain's immigration rules were found to violate Articles 14 and 8 (by providing less favourable treatment to the spouses and fiancé(e)s of

89 Although, as D. Harris et al point out (Law of the European Convention on Human Rights (London: Butterworths ,1995), pp 476-477) "the "badge" of differentiation relied on in the legislation or decision . . . may be challenged by the applicant as not being the "real" reason for distinguishing him from others". Having said this, the Court generally gives "short shrift [to] . . . claims attributing covert and discreditable motives to governments" (Ibid, pp 477, citing Abdulaziz, note 88 above, and Handyside v UK (1976) A 24).

90 (1968) A 6, 1 EHRR 252.

91 Note 90 above. Abdulaziz (note 88 above), for example, involved a challenge to an immigration rule which required that fiancés had previously met in order that the non-patrial be permitted access to the UK. The rule disproportionately disadvantaged those from the Indian sub-continent where arranged marriages were particularly common. In deciding that the rule was not discriminatory, however, the Court ignored its impact and examined only its aim (the prevention of bogus marriages). See Harris, pp 477-8. Harris also discusses $X$ v Ireland (1978) A 25 , in which the Court did not examine why no Loyalists were interned beyond the Government's statement that their activities were directed differently.

92 Note 90 above. In the Belgian Police and Swedish Engine Drivers cases (respectively, (1975) 1 EHRR 578 and (1975) 1 EHRR 617) the Court took an even more restricted approach to Article 14, asking only whether the treatment at issue had a justified aim in view or whether the authorities pursued "other and illintentioned designs. According to van Dijk and van Hoof (Theory and Practice of the European Convention on Human Rights $\left(2^{\text {nd }}\right.$, ed) (The Netherlands: Kluwer, 1990), pp 545-6): "Article 14 has been deprived of much of its meaning, since only those inequalities for which no objective and reasonable justification can be found are considered to conflict with it".

93 Bilka-Kaufhaus, Bilka-Kaufhaus GmbH v Weber von Hartz (case C-170/84) [1986] ECR 1607. See also the tendency, discussed by van Dijk and van Hoof, ibid, pp 545-6, to overlook the discriminatory nature of rules in considering the justifiability of their aims. 
patrial women than patrial men), Britain responded by withdrawing the more favourable treatment from the latter. ${ }^{94}$

Section 2 of the Human Rights Act 1998 provides that, in determining a question which has arisen in connection with a Convention right, courts and tribunals 'must take into account' the jurisprudence of the ECtHR and the ECmHR. This does not require that the domestic courts follow such jurisprudence - they could, of course, adopt a more generous approach than the Convention organs to the protection of Convention rights where no conflicting right is at issue. But the domestic courts are certainly not required to apply the EC approach to discrimination to Human Rights Act litigation. And, even in the unlikely event that they were minded so to do 95 , they might well be deterred by the fact that, although a disgruntled plaintiff can challenge domestic interpretation before the ECtHR, the respondent is unlikely to be able so to do. The State appears before the ECtHR only as respondent, the jurisdiction of that court being limited to breaches by Contracting Parties to the Convention (all of which are States). And even where the Human Rights Act is called into play in cases not involving the state (of which see more below), the respondent who wished to challenge an allegedly over-wide interpretation of the Convention rights could not do so unless s/he could point to another Convention right allegedly violated by this interpretation.

\section{State Action/ positive obligations}

We saw, above, that entrenched rights generally restrain rather than require state action, and are generally enforceable only against the State. Certainly, only States can appear as respondents before the ECtHR. But some of the Convention rights are defined in more positive terms (Article 2 stating that '[e]veryone's right to life shall be protected by law'; Article 8 that '[e]veryone has the right to respect for his [sic] private and family life, his [sic] home and his [sic] correspondence'). Certainly, the Convention organs have required positive action by Contracting Parties (in Airey ${ }^{96}$, the provision of practical access by way of financial assistance to particular litigants, in National Union of Belgian Police, an obligation to hear, though not necessarily to consult with, unions ${ }^{97}$ ). And in $X \mathrm{v}$ Federal Republic of Germany (1980) ${ }^{98}$ the Commission accepted that Contracting States which chose to act in areas covered by the Convention guarantees were obliged to do so without discrimination. ${ }^{99}$

94 See P. Gardner and C. Wickremasinghe, England and Wales and the European Convention, in B. Dickson (ed) Human Rights and the European Convention (London: Sweet \& Maxwell, 1997), p 83.

95 See A.McColgan, Equal Pay: Just Wages for Women (OUP, 1997) Chapters 3-5 and Discrimination: Text, Cases and Materials (Hart, 2000, forthcoming), passim, for critical discussion of the judicial approach to discrimination law.

96 (1981) A 41, 13 EHRR 622.

97 (1975) A 19. See also Swedish Engine Drivers' Union (1976) A 20, Marckx (1979) A 31, 2 EHRR 330, B v France (1994) A 232-C, 16 EHRR 1. Some measure of positive obligation was accepted also in Abdulaziz, note 87 above, Rees (1986) A 106, 9 EHRR 56 and Cossey (1990) A 184, 13 EHRR 622.

98 Note 87 above.

99 See the Canadian approach discussed above. 
The positive obligations recognised under the Convention extend also to the provision of some measure of protection against interference by private persons with Convention rights. In Young, James and Webster v UK ${ }^{100}$, the ECtHR accepted that Article 11 (freedom of association) required protection from interference by private parties. ${ }^{101}$ In $X$ and $Y \mathrm{v}$ Netherlands ${ }^{102}$ a similar conclusion was reached in respect of Article 8 and in $A$ v $U K$ the Court ruled that Article 3 (the right not to be subjected to degrading and inhuman treatment) was breached by a failure on the part of the state to protect from inhuman and degrading treatment at the hands of a private individual. ${ }^{103}$

As for the HRA itself, section 6 renders it unlawful for a 'public authority' to act incompatibly with a Convention right (unless bound so to do by primary legislation) and section 7 permits legal actions to be brought under the Act against public authorities (and public authorities alone). But the approach taken by the HRA is wide in two significant respects. First, courts are defined as 'public authorities' and are, therefore, bound to act compatibly with Convention rights unless bound by primary legislation to do otherwise. This has profound implications for the development of the common law, while section 3(1) imposes an express obligation upon the courts "[s]o far as it is possible to do so", to "read and give[] effect to" primary and subordinate legislation "in a way which is compatible with" the Convention rights incorporated. ${ }^{104}$ Secondly, section 6(6) of the HRA expressly defines the 'acts' of public authorities which must not be incompatible with Convention rights to include omissions, although the omissions thus covered do not extend to a failure to legislate.

\section{Implications of incorporation}

\section{Reproductive freedom}

Turning to the possible implications of implementation on some of the substantive areas considered above, a number of points can be raised. The incorporation of Article 2 will provide scope for challenge to the existing abortion regime. The ECtHR has yet to determine finally whether 'the right to life' extends to the foetus. ${ }^{105}$ The Commission has considered a number of cases involving abortion, upholding restrictive abortion legislation in Brüggeman and Scheuten v Federal Republic of Germany (1977) ${ }^{106}$ and rejecting (on the facts) a challenge to Great Britain's Abortion Act 1967 in

100 Appl. 7601/ 76 (1977) Yearbook XX 520.

101 See also Belgian Police case, note 93 above; and Plattform "Ärzte für das Leben" v Austria 13 EHRR 204 on freedom of assembly.

102 (1985) A 91.

10323 September 1998, available on the ECHR homepage: http://www.dhcour.coe.fr/.

104 See Schedule 1 for those included and McColgan, note 2 above, Chapter 10 for discussion of the omissions. For the controversy concerning the extent of the Human Rights Act's 'horizontal' application see R. Buxton, The Human Rights Act and Private Law (2000) 116 Law Quarterly Review 48, H Wade, Horizons of Horizontality (2000) 116 LQR 217, M. Hunt, The Horizontal Effect of the Human Rights Act [1998] Public Law 423.

105 See Open Door and Dublin Well Woman v Ireland (1993) 15 EHRR 244.

106 (1976) Yearbook XIX 382, (1978) 10 DR 100. 
Paton v United Kingdom (1980) ${ }^{107}$ while refusing to state definitively, as yet, whether the right to life protected under Article 2 extends to the foetus. ${ }^{108} \mathrm{~A}$ wide margin of appreciation is accorded to the Contracting States in this matter. But while the possibility remains that Article 2 extends to the foetus, incorporation may well spark a spate of attempts by putative fathers to prevent terminations. The British courts have tended to take a robust approach in these circumstances ${ }^{109}$. Armed with a possible right to life of the foetus, this stance might change. While the current Government has made it clear, in the House of Commons on October 21 1998, that abortion is one of the areas in which it might well chose not to act on a declaration of incompatibility, restrictive judicial interpretations of the Abortion Act may follow incorporation. Further, any 'right to life' of the foetus may well tip the balance, post-viability, in cases where a woman's views on the appropriate method of childbirth differ from those of her doctors.

In theory, if not always in practice, English common law upholds the right of pregnant women to bodily autonomy. ${ }^{110}$ There have been a number of cases in which women have been subjected to actual or threatened caesareans by court order ${ }^{111}$ and there is significant potential for abuse of the requirement that a patient must be 'competent' in order to veto medical opinion. ${ }^{112}$

In Re MB (1997) the Court of Appeal ruled that a "competent woman . . . may . . . choose not to have medical intervention, even though the consequence may be the death or serious handicap of the child she bears, or her own death" and that "the interests of the unborn child should not be taken into account by the courts". And in $\operatorname{Re} S$ the same Court ruled that: "The court does not have the jurisdiction to declare that [forced] medical intervention is lawful to protect the interests of the unborn child even at the point of birth." But the decisions, which alone stand between pregnant women's right to determine what is in the best interests of themselves and their prospective progeny, and rule by diktat of a profession which is frequently arrogant, blinkered and inclined to regard pregnant women as intellectually sub-normal ${ }^{113}$, turned on the absence of any right to life on the part of the foetus. To the extent that any such right were to be recognised, it could well be the case that these decisions would be reversed and forcible caesareans permitted by law.

107 Appl. 8416/79 (1980) 19 DR 244.

108 See also $H$ v Norway (1990), unreported, cited in Re MB [1997] 2 FCR 541, 38 BMLR 175, 1997 Fam Law 542, discussed in McColgan, note 2 above, Chapter 5.

109 Paton v Trustees of BPAS and Anor [1978] 2 All ER 987; Kelly v Kelly [1997] SLT 896, [1997] SCLR 749. See also $C$ v $S$ [1988] QB 135.

110 Re F [1988] 2 All ER 193, [1988] Fam 122, [1988] 2 WLR 1288, Re MB, note 108 above; $\operatorname{Re} S$ [1998] 3 All ER 673, [1998] Fam Law 526, discussed in McColgan, note 108 above.

111 Re MB, note 108 above; Re $S$ [1993] Fam 123, [1992] 3 WLR 806, [1992] 4 All ER 671, [1993] 1 FLR 26; Re $S$ (1998), ibid; Rochdale Healthcare (NHS) Trust v $C$ and Norfolk and Norwich HealthCare (NHS) Trust v W [1996] 2 FLR 613, [1997] Fam Law 17 and Tameside and Glossop Acute Services Trust v CH [1996] 1 FLR 762. See further McColgan, note 108 above.

112 Re L, unreported, Rochdale $\mathrm{v} C$ and Norfolk $\mathrm{v} W$; all discussed in McColgan, ibid.

113 See McColgan, ibid. 


\section{Women at work}

Turning next to the position of women in the employment sphere, incorporation may have some gap-filling interpretative potential ${ }^{14}$ and may provide some scope for challenge to procedural aspects of litigation (unavailability of legal aid in employment tribunals, delays associated with equal pay claims). But the former is likely to be severely constrained by the Convention jurisprudence in employment-related cases. The Convention organs have been very reluctant to apply its protections in the employment sphere. In Ahmad v UK, for example, the ECmHR dismissed, as manifestly unfounded, an Article 9 (freedom of religion) complaint by a Moslem teacher who was refused time off to attend Mosque on a Friday afternoon. According to the Commission, no interference had been established with his protected right given that he "remained free to resign if and when he found that his teaching obligations conflicted with his religious duties". A similar decision was reached in Stedman v UK, a claim brought by a woman sacked for refusing, on religious grounds, to agree to have her contractual terms varied to require Sunday working. The Commission reasoned that she had been dismissed for "failing to agree to work certain hours rather than her religious belief as such and was free to resign and did in effect resign from her employment". ${ }^{115}$

Workers have, on occasion, succeeded in establishing employment-related violations of their ECnHR rights. In Vogt $\mathrm{v}$ Germany ${ }^{116}$, a teacher successfully challenged her dismissal on grounds of her active membership of the German Communist Party. But in employment cases, it is fair to say that actionable interference with Convention rights is difficult to establish and easy to justify. ${ }^{177}$ As to the potential of the HRA for challenge to the non-availability of legal aid in employment tribunals, any such claim is unlikely to succeed. The ECtHR did recognise, in Airey v Ireland, that the non-availability of legal aid to a woman seeking a judicial separation order in a case involving allegations of physical and mental cruelty breached Article

114 Protection of lesbians by the Sex Discrimination Act, for example, contrary to the pre-Smith and Grady, Lustig-Prean and Beckett approach (these are at 29 EHRR 548 and 493 respectively), endorsed by the ECJ in Grant v South-West Trains [1998] ECR I-3739; development of protection against multiple discrimination (for example, by requiring interpretation of the SDA's indirect discrimination provisions to recognise disparate impact on particular groups of women defined by race or religion).

115 Respectively, 4 EHRR 126 and 23 EHRR CD. See also $X$ v Denmark (1976) 5 D\&R 157. These and other authorities are discussed in J. Bowers and J. Lewis, "Whistleblowing: freedom of expression in the workplace" 1 EHRLR 637 (1995) and K.D. Ewing, "The Human Rights Act 1998 and labour law" (1998) 27 Industrial Law Journal 275.

11621 EHRR 205. Cf Kosiek v Germany 9 EHRR 328, Glasenapp v Germany 9 EHRR 25.

117 See, for example, $X$ v $U K 45$ D \& R 41, Morissens v Belgium 56 D \& R 127, Ahmed $\vee U K$ [2000] EHRR 29 and $B$ v $U K 16 \mathrm{D} \& \mathrm{R} 101$, discussed by Bowers and Lewis, note 116 above, and by McColgan, "Freedom of expression and the Human Rights Act 1998: workers ungagged?”, in K. Ewing (ed) The Human Rights Act and Labour Law (London: Institute of Employment Rights, 2000) forthcoming. 
6. ${ }^{118}$ According to the Court, the Article: "is intended to guarantee not rights that are theoretical or illusory but rights that are practical and effective". But the case was an extreme one, the state itself standing between the plaintiff and her protected right (there to family life free of an abusive partner), and the ECtHR stressed that the right to effective access under Article 6(1) could have been satisfied by simplification of the proceedings such as to render a lawyer unnecessary, rather than by provision of legal aid. ${ }^{119}$ In $X \mathrm{v} U K^{120}$ (a challenge to the non-availability of legal aid before industrial tribunals) the Commission ruled that "only in exceptional circumstances, namely where the withholding of legal aid would make the assertion of a civil claim practically impossible, or where it would lead to an obvious unfairness of the proceedings, can such a right be invoked by Article 6(1)".

Of more significance from the perspective of this article is the potential of incorporation to operate against the interests of women in the workplace. The point here concerns the nature of entrenched rights primarily as a shield against government action, a device whereby the state can be reined in. It is true, and it has been pointed out above, that some measure of positive protection is required by the ECnHR jurisprudence. But as we have seen, the measure of this protection is severely constrained in the employment field.

To the extent that women are relatively disadvantaged, redress relies, by and large, on intervention by the state rather than arguments from entrenched rights. Such intervention is itself vulnerable to the entrenched rights of others. So, for example, in the US, affirmative action has been the subject of much constitutional challenge. And in Canada, the Charter has been used as a weapon by which men have challenged the provision of sex-specific maternity rights to women. ${ }^{121}$

It is to be expected that the implementation of the HRA will be followed by various challenges to maternity provision. It is unlikely that such actions will succeed in the final analysis, although they may well ensnarl the lower courts for a period of time. Of more significance perhaps is the potential of the HRA to counter any movements which might otherwise be made towards structural challenges to workplace discrimination against women (equally, against ethnic minority workers, the disabled, and other disadvantaged groups). Voices are currently raised in support of the imposition on employers of various monitoring duties, and of the enforcement of such duties by mechanisms including contract compliance. ${ }^{122}$ These voices are unlikely to be heeded in the short term. But, at the European level at least, there appears to be some recognition of the need for a more radical approach to discrimination than the individualistic model currently employed in the

118 Note 96 above. Art 6 specifically provides a right to legal aid in criminal cases.

119 See Munro v UK Appl. 10594/83, (1987) 52 D R 158.

120 Appl. 9444/81 6 EHRR 136.

121 See, for example, Schachter v Canada (1988, eventually in the Supreme Court at [1992] 2 SCR 679) and Schafer v Canada (1988) 18 FTR 199, Ontario Court of Appeal, 8 August 1997), discussed by McColgan, note 2, Chapters 7 and 10.

122 See, for example, B. Hepple, M. Coussey and T. Choudhury, Equality; A New Framework (Report of the Independent Review of the Enforcement of UK AntiDiscrimination Legislation) (Cambridge: University of Cambridge, Centre for Public Law and the Judge Institute of Management Studies, 2000). 
UK. ${ }^{123}$ To the extent that any such shift could be categorised as a move to 'affirmative action', 'positive' or 'reverse' discrimination, the resistance will come waving copies of the HRA.

The other issue which might arise concerns the role of collective bargaining reducing the gender-pay gap. Freedom of association is a protected Convention right (Article 11). But the jurisprudence is less than impressive, perhaps the most significant decision on freedom of association being Young, James and Webster $\mathrm{v} U K^{124}$, which sealed the death warrant for the British closed shop. The ECtHR has accepted that freedom of association extends beyond the bare right to be a member of a trade union. ${ }^{125}$ But, while the Convention Organs have been ready to interpret Article 11 to restrict the rights and freedoms of trade unions ${ }^{126}$, the Court has yet to uphold a single application alleging breach of trade union rights under Article 11.

The new recognition provisions mean that domestic law is almost certainly compliant with Article 11, if indeed it was not before. ${ }^{127}$ And the hostility displayed by the domestic judiciary towards trade unions make it inconceivable that their interpretation of Article 11 would be more generous than that of the Convention organs. ${ }^{128}$ It is entirely possible, however, that judicial application of Articles 6, 10 and 11, and of the right to property enshrined in the First Protocol to the Convention (and incorporated by the HRA) will result in the shackling of the CAC's discretion in the recognition proceedings, the judicial protection of employer freedom to campaign against recognition votes and to restrict trade union access to workplaces, and so forth. ${ }^{129}$

\section{Women as victims of violence}

We have seen that entrenched rights impact both on procedure (the admissibility of evidence, and so forth) and on the substance of the criminal law. The potential of entrenched rights to improve the quality of justice afforded to criminal defendants is, of course, a benefit. But, to the extent that

123 Note the movement of the ECJ from Kalanke v Freie Hansestadt Bremen (Case 450/93) [1996] All ER (EC) 66 to Marschall v Land Nordrhein-Westfalen (Case C-409/95) [1997] All ER (EC) 865 and Badeck \& Ors v Landesanwalt beim Staatsgerichtshof des Landes Hessen Case C-158/97 [2000] All ER (EC) 289; the amendment of old Article 119 of the Treaty expressly to permit positive action and the express acceptance by the new race discrimination directive (Council Directive 2000/43/EC) and the draft equal treatment general framework directive (available at http://europa.eu.int/eur-lex/en/com/reg/en_register_ 052005.html).

124 (1982) EHRR 38.

125 Belgian Police, note 92 above. $C f$ the House of Lords in Associated Newspapers v Wilson, Associated British Ports v Palmer [1995] IRLR 258, discussed below.

126 See also X v Belgium Yearbook IV (1970) p 708, for example, Cheall v UK Yearbook XIV (1971) p 198, Appl. 4125/69 and Sigurjonnson v Iceland (1993) 16 EHRR 462

127 The ECtHR decision in Wilson \& NUJ, Palmer, Wyeth \& RMT and Doolan \&Ors (Appls. 30668/96, 30671/96 and 30678/96), (the ECmHR admissibility decision in which is available at: http://www.dhcour.coe.fr/hudoc/default/asp?Language=en\&Advanced=1), is awaited.

128 See McColgan, note 2 above, Chapter 10.

129 This is further discussed by McColgan, ibid. 
the judiciary is permitted to pass judgement upon the substance of the criminal law or upon statutory procedural rules, entrenchment serves to insulate the common law from democratic reform. That common law has proved itself hostile to the needs and interests of women.

Article 6 of the ECtHR requires a "fair and public hearing within a reasonable time by an independent and impartial tribunal established by law" in the determination of criminal charges as well as enshrining the presumption of innocence and affording, inter alia, the accused the right "to defend himself in person or through legal assistance" to "to examine or have examined witnesses against him". It is distinctly possible that Article 6 will be wielded by the domestic judiciary to challenge the long-overdue provisions of the Youth Justice and Criminal Evidence Act 1999 which attempt to restrict the use of complainants' sexual history evidence in rape trials as well as to prevent the accused from cross-examining the complainant himself in these cases. The 1999 provisions were necessitated, in part, by judicial reluctance to apply the restrictions on sexual history evidence previously established by the Sexual Offences (Amendment) Act 1976.

The 1976 Act restricted the admission of sexual history evidence to cases in which it would have been permitted at common law and, on application by the accused, the judge decided it would be unfair to him to exclude it. The operation of the 1976 Act has been discussed elsewhere, ${ }^{130}$ it being sufficient to note that the judiciary interpreted the Act so as to make admissible what would not have been at common law and to exclude only that evidence which was alleged to be relevant to the complainant's credibility on the bare assumption that unchaste women lie about sex. There is an abundance of evidence that juries do not convict men of raping women who are seen to be sexually 'available' (that is, who have any history of sexual activity outside marriage). ${ }^{131}$ Thus, the promiscuous admission of sexual history evidence in rape trials contributed to the high acquittal rates therein and, at least as significantly, deterred many women from prosecuting.

Judges having proven themselves unworthy of the discretion vested in them by the 1976 Act, the 1999 Act's approach replaces the open-ended question of unfairness with a provision that sexual history evidence may only be adduced, or a question asked thereon, if it both falls within one of a closed number of exceptions to the general prohibition and the judge is satisfied that its exclusion "might have the result of rendering unsafe" a conclusion of jury or court. The reaction of the judicial element of the House of Lords to this reform points to the wisdom of having refrained from handing over to them the power to strike down primary legislation, as distinct from simply declaring it incompatible with the ECnHR.

Their Lordships were adamantly of the view that the existing safeguards (both in terms of cross-examination by rape defendants and admission of

130 A. McColgan, Common law and the relevance of sexual history evidence (1996) 16 Oxford Journal of Legal Studies 275.

131 For lawyers' awareness and exploitation of this, see remarks by Lord Lester during the Committee stage of the Bill, 8 February 1999 col. 61, citing research carried out by Jennifer Temkin. 
sexual history evidence) were perfectly adequate. ${ }^{132}$ The real gaps between the judges and the legislators on this issue were that the former were convinced (a) that cross-examination by the defendant was problematic only if 'improperly' conducted, and that judicial control of the substance was adequate $^{133}$ and (b) that sexual history evidence was properly admitted as going to the issue of consent ${ }^{134}$; whereas the latter took the view (a) that the prospect of cross-examination by a rapist would deter many rape victims from reporting ${ }^{135}$ and (b) that a woman's sexual behaviour on other occasions would very rarely be relevant to the question whether she consented to the defendant ${ }^{136}$.

It being clear from the House of Lords' debates that the 1999 provisions are regarded by the judiciary as excluding 'relevant' evidence, it is presumably a matter of time before they are declared incompatible with the incorporated provisions of the ECnHR. Given the government's firm view supported, inter alia, by prominent human rights lawyer Lord Lester, that the provisions

132 See, for example, Lord Bingham LCJ in the House of Lords debate on the Second Reading of the Bill, 15 December 1998, cols. 1269 ff; Lord Ackner at cols. 1276 ff, at Committee stage 8 February 1999 cols.42ff and the Report stage HL Debs 8 March 1999 cols 12ff. Referring to the Lord Chief Justice's report of judicial "outrage and disbelief" at allegations that the 1976 provisions were being improperly applied Lord Williams of Mostyn remarked $\left(8^{\text {th }}\right.$ February 1999 , col.58) "The proposition that six men falsely accused of terrorist offences in Birmingham had been wrongly accused was met year upon year by the judiciary ... with outrage and disbelief. Indeed that was not the only occasion when our system determined that outrage and disbelief were not necessarily the safest guides to the most just outcome".

133 Lord Bingham, ibid and at the Committee stage, HL Debs 1 February 1999, cols. 1400 ff; Lord Ackner, ibid and at Committee stage HL Debs 8 February 1999 cols.19ff.

134 Lord Bingham, ibid; Lork Ackner ibid.

135 Lord Williams of Mostyn HL Debs, 15 December 1998, cols. 1302 ff, $1^{\text {st }}$ February cols. $1404 \mathrm{ff}$ and Committee stage 8 February 1999, cols. 58ff; Baroness Kennedy, $15^{\text {th }}$ December 1998, cols.1401 ff

136 Lord Williams of Mostyn, Report stage, HL Debs 8 March 1999 col. 33: "I assert again. . . that the fact that a woman has consented to sexual activity on an earlier occasion, with perhaps another man in different circumstances, is not relevant to whether she consented to sexual relations with the defendant on a particular occasion. That is a matter that one either accepts or does not accept. . I shall not resile from that proposition". See also Lord Lester, Report stage, 8 March 1999 col. 22 "It seems to me that in most cases evidence of previous sexual promiscuity is irrelevant, or should be irrelevant, and is inadmissible or should be inadmissible in relation to the issue of consent as distinct from honest belief in consent. . . Lord Ackner, and. . . Lord Thomas of Gresford. . . believe there is a wider category of cases in which evidence of the complainant's previous sexual history is relevant, ought to be able to be admitted, and is not greatly prejudicial to the dignity and other rights of the complainant. So there is a disagreement in principle. With respect, it does not do to cite existing case-law on that subject if the disagreement is within the attitudes displayed in that case-law on the one hand and what the Government seek to do . . . on the other, which is indeed to change the unsatisfactory status quo". 
are entirely consistent with the Convention, it is to be hoped that any such declaration will not result in amendment to the legislation. ${ }^{137}$

It has been mentioned throughout that the perpetrators of violence against women are not themselves bound by the provisions of the ECnHR as incorporated into domestic law by the HRA. Nor is it likely that incorporation will assist the lot of those women who kill their abusive partners. Elsewhere, most notably in Canada, the self-defensive nature of some such killings has begun to be recognised by the courts, although there is evidence that women are pressurised into accepting manslaughter pleas for fear of failing in a self-defence claim. ${ }^{138}$ Here, the use of self-defence by battered women killers is virtually unknown, not least perhaps because of the unavailability of a partial defence of excessive use of force in self-defence as a back-up plea. ${ }^{139}$ But if the courts were minded to look afresh at the traditional models of self-defence in order to apply the core principles of that defence to the circumstances in which women kill out of fear for their own lives or the lives of their children, it is at least possible that the HRA would deter them from so doing. In McCann, Farrell and Savage v UK (1996), the ECtHR ruled that Article 2 of the ECnHR permits the use of "no more force than absolutely necessary" 140 in self-defence, a test considerably more rigorous than that which currently prevails in domestic law. ${ }^{141}$

The only way in which incorporation might benefit battered women, together with the victims of rape, lies in Article 8's "right to respect for . . . private and family life". It has been accepted that this provision requires "the adoption of measures designed to secure respect for private life even in the sphere of the relations of individuals between themselves" and that "respect for private life" in turn includes access to legal redress in the case of sexual assault and domestic violence. This approach was taken by the Court in $X$ and $Y \mathrm{v}$ Netherlands, discussed above. ${ }^{142}$ Equally, in the wake of $A \mathrm{v} U K$ $(1998)^{143}$, it could be argued that the failure of the legal system adequately to protect women from violence at the hands of their partners breaches Article 3. But the obstacle in $X$ and $Y$ was legal and absolute, and the violation in $A$ $\mathrm{v} U K$ lay in the law, rather than in practice.

The difficulties experienced by rape complainants are, in large part, inherent in the private nature of the crime, the widespread distrust of women who complain of it and the prevailing view that 'consent' in the context of sexual intercourse is a 'fuzzy' concept. It is hard to imagine that any positive obligations imposed on the state by the ECnHR extend to ensuring the conviction of the guilty, as distinct from the possibility of criminal prosecution.

137 HL Debs 1 February 1999, cols. 1395 ff. For further discussion of this see McColgan, note 108 above.

138 See note 83 above.

139 See further McColgan, "In defence of battered women who kill" (1993) 13 Oxford Journal of Legal Studies 508.

140 (1996) A 324, 21 EHRR 97.

141 See McColgan, note 139 above.

$142 X \& Y$ v Netherlands, note 102 above.

143 Note 103 above. 


\section{CONCLUSION}

The aim of this article has been to point out some of the pitfalls associated with entrenched rights in general and, in particular, with the Human Rights Act 1998. I have chosen to focus on women, and then only in particular spheres, but a number of conclusions can be extrapolated more generally. The first point concerns the relative importance of rights and the wider political context in which they operate. Entrenched rights - in particular the type of rights adopted by the UK - are limited in their scope and their impact. They cannot provide a substitute for political action and they can threaten legislative action designed to ameliorate disadvantage.

The dangers posed by constitutional rights are particularly acute where, as here, the rights leave much to be desired. The ECnHR was adopted in the aftermath of the second world war by a Europe preoccupied with the more extreme end of human rights abuses. The Convention was regarded as a first step rather than an ultimate statement of rights. In particular, it is silent as to 'social' rights such as rights to work, housing, social security, protection of health, minimum working conditions, fair remuneration, and free collective bargaining ${ }^{144}$. And while it could be argued that any rights are better than none at all, the HRA's failure to balance the Convention rights with those secured by the European Social Charter creates the danger that the latter will be further marginalised. Further, concerns associated with the shift in power from legislature to judiciary have been mentioned throughout.

Rights do not exist in a vacuum, but have to be balanced against other rights. The question which must be asked is whether the legislature or the judiciary has shown itself best suited to perform the necessary balancing act. In the UK, in those areas which have formed the substantive subject matter of this article, the best that can be said of the judiciary is that its attitude has been highly questionable. The legal strides which have been made by women over the last decades are, by and large, thanks to the efforts of the legislature rather than the judiciary.

144 All of which are contained in Council of Europe's Social Charter, which must be distinguished from that adopted by the European Community and subsequently incorporated into the Social Chapter appended to the Treaty of European Union by the Maastricht Treaty, and subsequently into the TEU itself by the Amsterdam Treaty.. 